mgr inż. Ewa Sobór ${ }^{1}$

mgr inż. Marta Gołaszewska ${ }^{1}$

mgr inż. Michał Chmiel ${ }^{1}$

mgr inż. Michał Borusiński ${ }^{2}$

Przyjęty/Accepted/Принята: 14.10.2014;

Zrecenzowany/Reviewed/Рецензирована: 23.05.2015;

Opublikowany/Published/Опубликована: 30.06.2015;

\title{
Znaczenie systemu dopuszczeń pojazdów pożarniczych w kontekście zapewnienia bezpieczeństwa strażaków ${ }^{3}$
}

\author{
Importance of Firefighting Vehicles Admittance Process in the Context \\ of Providing Safety for Firefighters
}

\section{Значение системы допусков пожарных транспортных средств в контексте обеспечения безопасности пожарных}

\begin{abstract}
A B S T R AKT
Cel: Celem artykułu jest przedstawienie znaczenia kolejnych etapów procesu dopuszczania do użytkowania pojazdów pożarniczych w kontekście zapewnienia bezpieczeństwa strażaków.

Wprowadzenie: Użytkownicy końcowi, decydując się na wybór danego sprzętu pożarniczego, oczekują spełnienia przede wszystkim trzech warunków: bezpieczeństwa, ergonomii i funkcjonalności. Co więcej wysoka skuteczność oraz niezawodność działania wyposażenia i sprzętu wykorzystywanego do działań ratowniczo-gaśniczych przez jednostki ochrony przeciwpożarowej jest warunkiem koniecznym do spełnienia z uwagi na powodzenie prowadzonych działań oraz zapewnienie bezpieczeństwa zarówno osób ratowanych, jak i samych ratowników. Aby wyjść naprzeciw wymaganiom i potrzebom jednostek ochrony przeciwpożarowej w Polsce wprowadzono system dopuszczeń. W niniejszym artykule, na przykładzie pojazdów pożarniczych, przedstawiono kolejne etapy procesu dopuszczenia wyrobów do użytkowania oraz ich znaczenie dla bezpieczeństwa strażaków. Omówiono aktualne przepisy prawa w zakresie dopuszczania pojazdów do użytkowania oraz przedstawiono główne założenia oraz przebieg procesu dopuszczenia. Zwrócono również uwagę na znaczenie nadzoru nad udzielonymi dopuszczeniami, realizowanego na drodze kontroli dopuszczeń. Poruszono również kwestie posługiwania się świadectwem dopuszczenia, odpowiedzialności za wyrób oraz wprowadzania zmian mogących mieć odzwierciedlenie w zapisach świadectwa dopuszczenia.

Metodologia: W artykule przeanalizowano literaturę przedmiotu. Treść opracowano w oparciu o aktualnie obowiązujące przepisy prawa w zakresie zarówno wprowadzania samochodów pożarniczych do użytkowania, jak i ich klasyfikacji, podziału oraz oznaczenia. Literaturę stanowią dodatkowo procedury opracowane przez Jednostkę Certyfikującą CNBOP-PIB.

Wnioski: System dopuszczeń oparty na ściśle określonych wymaganiach i sposobie postępowania stanowi skuteczne narzędzie selekcji pojazdów pożarniczych trafiających na polski rynek. Znaczenie tego systemu dla bezpieczeństwa jednostek ochrony przeciwpożarowej jest znaczące. Dostarcza on bowiem odbiorcom szereg istotnych informacji na temat przedmiotowych wyrobów, co ułatwia podjęcie decyzji $\mathrm{w}$ zakresie zakupu pojazdu wprowadzonego do użytkowania na zasadach zgodnych $\mathrm{z}$ aktualnie obowiązującymi przepisami prawa oraz spełniającego nie tylko oczekiwania samych użytkowników końcowych, ale i przede wszystkim wymagania z uwagi na ich bezpieczeństwo.
\end{abstract}

Słowa kluczowe: znaczenie, system dopuszczeń, dopuszczenie do użytkowania, pojazd, pojazd pożarniczy, samochód pożarniczy, podział, klasyfikacja, oznaczenie, WTO, kontrola dopuszczenia

Typ artykułu: $z$ praktyki dla praktyki

\footnotetext{
1 Centrum Naukowo-Badawcze Ochrony Przeciwpożarowej - Państwowy Instytut Badawczy, Józefów / Scientific and Research Centre for Fire Protection National Research Institute, Poland; mchmiel@cnbop.pl;

2 Akademia Obrony Narodowej, Warszawa / National Defence University, Warsaw, Poland;

3 Wkład merytoryczny w powstanie artykułu / Percentage contribution: E. Sobór - 20\%, M. Gołaszewska - 40\%, M. Chmiel - 30\%, M. Borusiński - 10\%;
} 


\section{A BSTRACT}

Aim: The purpose of this article is to expose the importance of the admittance process for firefighting vehicles from the viewpoint of firefighters' safety.

Introduction: During the selection process, involving firefighting equipment, end users focus on the satisfaction of three conditions; safety, ergonomics and functionality. Moreover effectiveness and equipment reliability during operations are prerequisites, which must be satisfied, to achieve successful outcomes and ensure the safety of incident victims and firefighters. In order to satisfy demands and needs of Fire Service establishments, Poland introduced an admittance process. This article has identified sequential stages of the admittance process, involving equipment destined for use, using vehicle acquisitions for illustrative purposes and discussed the significance of the process from the viewpoint of firefighters' safety. In parallel with discussions about current legislation dealing with admittance of equipment, the article exposed main assumptions used and the course of the admittance process. Attention was also drawn to the issue of supervision over the granting of certificates od admittance, performed as part of the admittance control mechanism. Additionally, the article discussed issues associated with the use of certificates od admittance, product liability and introduction of modifications to equipment, which may be reflected in certificates of admittance.

Methods: The authors carried out an analysis of literature dealing with the topic. The article was based on sources of law, which are currently in force and apply, not only to bringing into use but also classification, division and rules of designation. Moreover, procedures developed by CNBOP-PIB Certification Department formed part of the literature source.

Conclusions: The admittance process, based on specific requirements and procedures, is an effective tool for selection of firefighting vehicles, from those available on the Polish market. The importance of this system to the safety of Fire Service personnel is significant. It provides users with important information about products. Such information simplifies purchasing decisions involving vehicles introduced for use in accordance with current legislation, which, not only satisfy user expectations but above all address requirements concerning safety.

Type of article: best practice in action

Keywords: significance, admittance system, admittance, vehicle, firefighting vehicle, division, classification, rules of designation, admittance control

\section{АННОТАЦИЯ}

Цель: Целью статьи является представление важности очередных этапов процесса допуска к использованию пожарных транспортных средств в аспекте безопасности пожарных подразделений пожарной охраны.

Введение: Конечные потребители, решившие покупать конкретное противопожарное оборудование в первую очередь ожидают, что оно исполнит как минимум три главные условия: безопасности, эргономичности и функциональности. Кроме того, высокая эффективность и надёжность оснащения и оборудования, используемого во время спасательно-гасящих действий подразделениями пожарной охраны, необходимы для успеха проводимых действий и обеспечения безопасности как спасаемых людей, так и самих спасателей. Чтобы удовлетворить требования и потребности подразделений пожарной охраны, в Польше была введена система допусков. В данной статье, на примере пожарных транспортных средств, представлены очередные этапы процесса допусков изделий к использованию, а также их важность для безопасности пожарных. Кроме рассмотрения действующих правовых актов о допуске пожарных транспортных средств к использованию, были также представлены главные предположения и ход процесса предоставления допуска. Обращено также внимание на суть надзора за выданными допусками, который осуществляется в процессе контроля допусков. Были также рассмотрены вопросы использования свидетельств допуска, ответственности за изделие и внесение в него изменений, которые могут отражаться в записях свидетельства допуска. Методология: В статье была проанализирована предметная литература. Содержание было разработано на основе действующих нормативных актов относительно введения пожарных машин для использования, а также их классификации, разделения и маркировки. Литература включает также процедуры, разработанные Сертификационным Департаментом CNBOP-PIB. Выводы: Система допусков, с конкретно определёнными требованиями и процедурами, представляет собой эффективный инструмент выбора пожарных транспортных средств, поступающих на польский рынок. Значение этой системы для безопасности подразделений пожарной охраны - существенное. Так как она предоставляет заказчикам широкую информацию на тему определённых продуктов, помогая таким образом принять им решение относительно покупки транспортного средства, введенного в эксплуатацию на условиях, отвечающих актуально действующим правовым актам и требованиям конечных потребителей, но в главном - требованиям безопасности.

Ключевые слова: значение, система допусков, допуск к использованию, транспортное средство, пожарное транспортное средство, разделение, классификация, маркировка, технически-организационные условия продукции, контроль допусков

Вид статьи: с практики для практики

\section{Wstęp}

Charakter zagrożeń, z którymi w dzisiejszych czasach mierzy się straż pożarna, jest bardzo zróżnicowany. Obok pożarów są to również wypadki drogowe, powodzie, czy incydenty związane z substancjami niebezpiecznymi. Specyfika zdarzeń, na którą muszą być przygotowani strażacy, ewoluuje wraz z ciągłym postępem technologicznym. W ciągu przeszło 20 lat funkcjonowania Państwowej Straży Pożarnej sprzęt wykorzystywany do działań był i w dalszym ciągu jest doskonalony i dostosowywany do stale zmieniających się warunków pracy, jak również z uwagi na oczekiwania użytkowników końcowych.

Dla prowadzących działania ratowniczo-gaśnicze niezwykle istotne jest dostosowanie sprzętu do charakteru zdarzenia, jak również zagwarantowanie bezpieczeństwa podczas jego użytkowania. Dotyczy to zarówno bezpieczeństwa ratujących, jak i ratowanych. Dodatkowo sprzęt wykorzystywany 
w działaniach powinien zapewniać możliwie najwyższy komfort pracy, co niewątpliwie wpłynie na jej efektywność. Mając na uwadze oczekiwania osób, którym dedykowany jest sprzęt ratowniczo-gaśniczy, blisko 8 lat temu wprowadzono w Polsce system dopuszczeń. Jego głównym założeniem jest selekcja wyrobów trafiających na polski rynek przeznaczonych do użytkowania przez jednostki ochrony przeciwpożarowej wskazane w art. 15 ustawy o ochronie przeciwpożarowej [1].

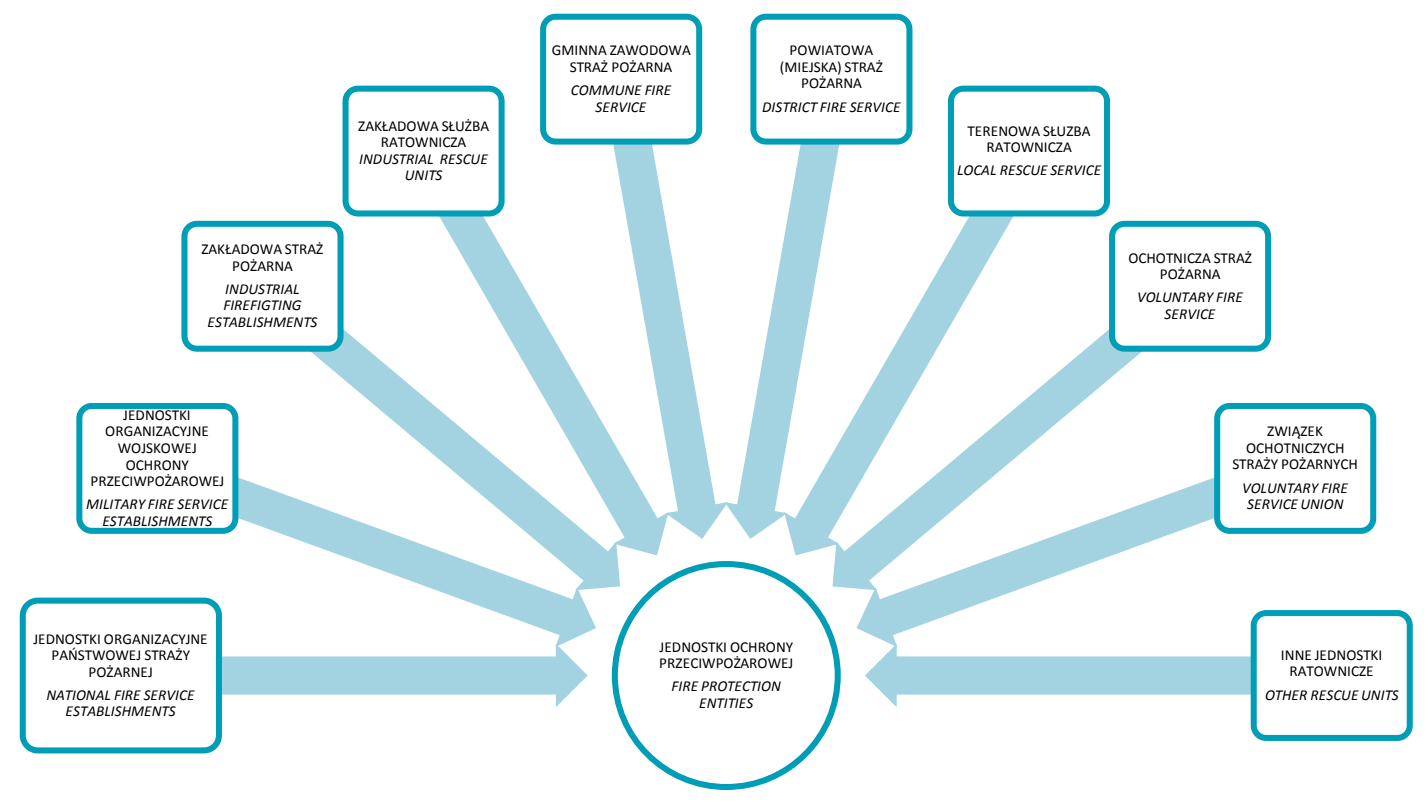

Ryc. 1. Jednostki ochrony przeciwpożarowej

Fig. 1. Fire protection entities

Źródło: Opracowanie własne na podstawie art. 5 Ustawy o ochronie przeciwpożarowej [1]

Source: Own elaboration based on Fire Protection Act, article 5 [1]

Dzięki regulacjom wynikającym $z$ artykułu 7.1. ustawy [1] stanowiącym o tym, że wyroby służące zapewnieniu bezpieczeństwa publicznego lub ochronie zdrowia i życia oraz mienia, wprowadzane do użytkowania w jednostkach ochrony przeciwpożarowej oraz wykorzystywane przez te jednostki do alarmowania o pożarze lub innym zagrożeniu oraz do prowadzenia działań ratowniczych, a także wyroby stanowiące podręczny sprzęt gaśniczy, mogą być stosowane wyłącznie po uprzednim uzyskaniu dopuszczenia do użytkowania, świadectwa dopuszczenia zyskały charakter obligatoryjny. Obowiązek ich uzyskania wynika ze wspomnianej ustawy [1] oraz aktu wykonawczego, to jest rozporządzenia MSWiA z 20 czerwca 2007 roku [2].

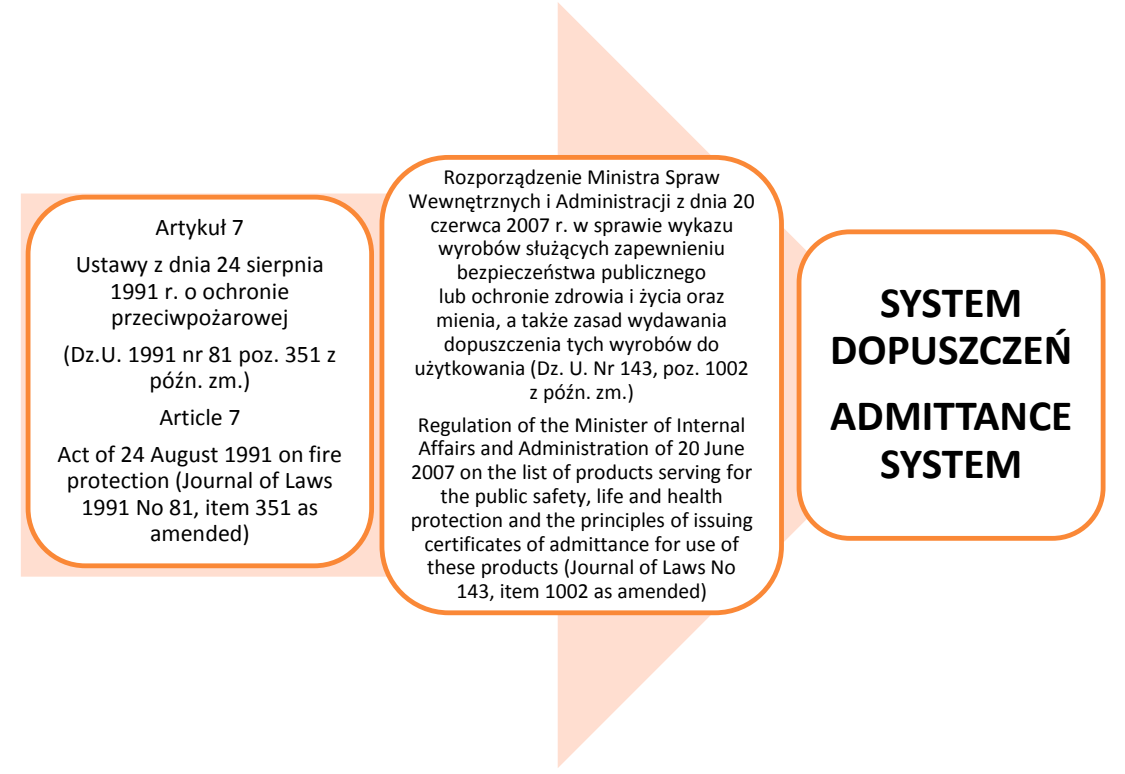

Ryc. 2. Akty prawne regulujące obowiązek przeprowadzania procesu dopuszczenia

Fig. 2. Legislation governing the obligation of carrying out the admittance process Źródło: Opracowanie własne. Source: Own elaboration. 
Załącznik do rozporządzenia [2] zawiera, obok wykazu wyrobów podlegających obowiązkowi uzyskania świadectwa dopuszczenia, wymagania, jakie należy spełnić $\mathrm{w}$ procesie dopuszczenia. Wymagania te w przypadku pojazdów pożarniczych związane są bezpośrednio z normami wyrobu, to znaczy PN-EN 1846-1:2011 [3] oraz PN-EN 1846-2+A1:2013-07 [4], oraz uzupełnione o krajowe wymagania techniczno-użytkowe (tzw. wymagania szczegółowe), które dotyczą przykładowo oznakowania pojazdu czy wyposażenia zamontowanego na stałe. Jednostką upoważnioną do prowadzenia procesów dopuszczenia do użytkowania w ochronie przeciwpożarowej jest CNBOP-PIB.

\section{Dopuszczenie do użytkowania pojazdów pożarniczych}

Z doświadczeń CNBOP-PIB w zakresie prowadzenia procesów dopuszczenia oraz biorąc pod uwagę specyfikę wyrobu wynika, iż spośród wszystkich wyrobów objętych obowiązkiem przeprowadzenia procesu dopuszczenia na szczególną uwagę zasługują pojazdy pożarnicze. W celu najbardziej optymalnego przedstawienia przebiegu oraz istoty procesu ze szczególnym uwzględnieniem aspektu bezpieczeństwa strażaków, warto w tym miejscu nieco przybliżyć tematykę, przedstawiając kilka definicji związanych z pojazdami pożarniczymi.

$\mathrm{Na}$ podstawie aktualnie stosowanych norm PN-EN 1846-1 [3] oraz PN-EN 1846-2 [4], stanowiących podstawę klasyfikacji i podziału pojazdów pożarniczych wyróżnić możemy następujące terminy i definicje:

- Pojazdy ratowniczo-gaśnicze - pojazdy o zabudowie pożarniczej wyposażone w pompę pożarniczą i zazwyczaj w zbiornik wody oraz w inny specjalistyczny sprzęt i/lub środki gaśnicze niezbędne do prowadzenia akcji ratowniczo-gaśniczej.

- Pojazdy z drabiną mechaniczną - pojazdy pożarnicze wyposażone w konstrukcję wysuwaną zamontowaną na obrotowej podstawie. Konstrukcja ta posiada przęsła w kształcie drabiny, która może dodatkowo zawierać kosz ratowniczy.

- Pojazdy z podnośnikiem hydraulicznym - pojazdy wyposażone w podnośnik hydrauliczny, który składa się z kosza i wysięgnika hydraulicznego, zamontowanego na podstawie, wykorzystywany w działaniach ratowniczo-gaśniczych. Podnośnik hydrauliczny może być dodatkowo wyposażony w działko gaśnicze.

- Samochód ratownictwa medycznego - pojazd samochodowy o konstrukcji przystosowanej do opieki i przewozu osób poszkodowanych.

- Samochód ratownictwa technicznego - pojazd samochodowy wyposażony w sprzęt niezbędny do podjęcia akcji ratowniczych takich jak: poszukiwania ludzi, usuwania skutków wypadków, awaryjnego odblokowania wejść, ratowania zwierząt.

- Samochód sprzętowy ratownictwa chemicznego pojazd samochodowy z wyposażeniem umożliwiającym prowadzenie akcji ratowniczych takich jak: poszukiwania i ratowania osób, usuwanie skutków wypadków, awaryjnego odblokowywania wejść, ratowania zwierząt.

- Samochód dowodzenia i łączności - samochód o zabudowie pożarniczej wyposażonej w środki łączności i sprzęt niezbędny do prowadzenia działań dowódczych.

- Samochód do przewozu personelu - samochód pożarniczy do transportu personelu wraz z wyposażeniem.

- Samochód zaopatrzeniowy - samochód o zabudowie specjalnie przystosowanej do przewozu sprzętu lub środków gaśniczych do celów zaopatrywania jednostek będących w akcji.

- Inne specjalne pojazdy samochodowe.

W strukturach jednostek ochrony przeciwpożarowej możemy również wyróżnić inne grupy pojazdów specjalnych, przyczep i naczep, samolotów, śmigłowców, kontenerów oraz łodzi.

Norma PN-EN 1846-1 [3] określa, obok różnych kryteriów stosowanych w odniesieniu do pojazdów pożarniczych, klasy i kategorie samochodów pożarniczych w zależności od przeznaczenia i masy.

- Masa nieobciążonego samochodu - masa pojazdu wraz $\mathrm{z}$ kierowcą (75 kg), sprzętem niezbędnym do obsługi samochodu (z wyłączeniem koła zapasowego), z pełną ilością cieczy chłodzącej, paliwa, oleju i z wyposażeniem zamontowanym na stałe, lecz bez środka gaśniczego.

- Maksymalna masa rzeczywista (MMR) - masa nieobciążonego samochodu, dodatkowo uwzględniona o masę pozostałych członków załogi, dla której samochód został zaprojektowany (90 kg na każdego członka załogi wraz z wyposażeniem, oraz dodatkowego $15 \mathrm{~kg}$ na wyposażenie osobiste kierowcy), masę środka gaśniczego wraz z pozostałym wyposażeniem które ma być przewożone.

Mając na uwadze powyższe definicje, podział pojazdów przedstawia się następująco:

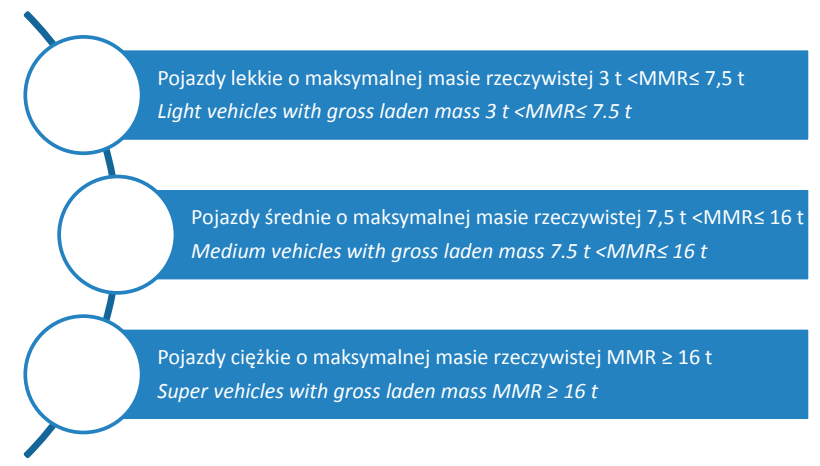

Ryc. 3. Podział pojazdów pożarniczych ze względu MM [5]

Fig. 3. Classification of firefighting vehicles according to their gross laden mass [5]

Należy nadmienić, iż znajomość podziału pojazdów z uwagi na ich masę jak również przeznaczenie użytkowe jest niezwykle istotna przy ustalaniu ich oznaczenia. Przykładowo:

Oznaczenie średniego samochodu ratowniczo-gaśniczego ze zbiornikiem wody o pojemności 2500 l i pompa pożarnicza o parametrach $8 \mathrm{bar} / 1600 \mathrm{l} / \mathrm{min}$, z agregatem prądotwórczym. 


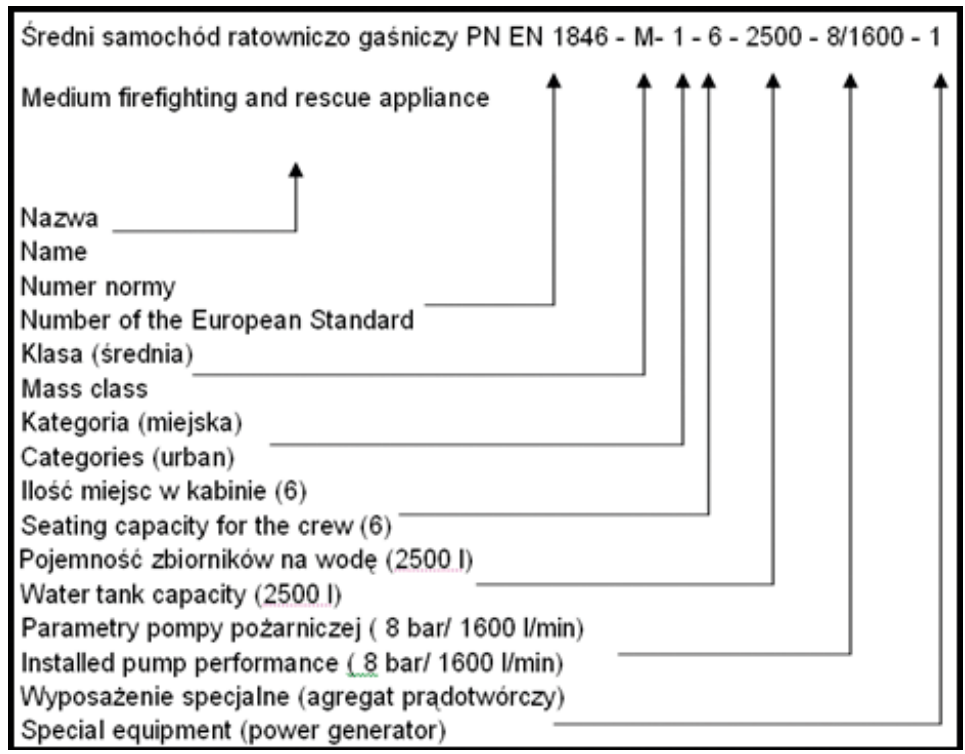

Ryc. 4. Oznakowanie średniego samochodu ratowniczo-gaśniczego [5]

Fig. 4. Marking of a medium firefighting and rescue vehicle [5]

Proces dopuszczenia pojazdów pożarniczych inicjowany jest przez wnioskodawcę poprzez złożenie wniosku o przeprowadzenie procesu dopuszczenia wyrobu do użytkowania. W dalszej kolejności wykonywane są badania laboratoryjne poprzedzone szczegółową analizą dokumentacji wyrobu. Badania na potrzeby procesu dopuszczenia wykonywane są w laboratoriach akredytowanych. Zakres badań koniecznych do przeprowadzenia opracowywany jest na podstawie wymagań techniczno-użytkowych oraz konkretnych norm polskich zawartych w załączniku do rozporządzenia [2]. Na tym etapie najczęściej identyfikowanym problemem, obok nieaktualnego druku lub niewłaściwie wypełnionego formularza wniosku o przeprowadzenie dopuszczenia wyrobu do użytkowania, jest niekompletna dokumentacja wyrobu uniemożliwiająca jego dokładną identyfikację, a co za tym idzie, opracowanie właściwego programu badań. Kolejną integralną częścią procesu dopuszczenia wyrobu do użytkowania jest ocena warunków techniczno-organizacyjnych (WTO). Jest to systematyczny, niezależny, udokumentowany proces uzyskiwania dowodów, stwierdzenia faktów bądź innych odpowiednich informacji oraz ich obiektywnej oceny, mający na celu określenie stopnia spełnienia wymagań, które zapewniają stabilną jakość produkcji wyrobów zgodnych $\mathrm{z}$ mającymi zastosowanie technicznymi dokumentami odniesienia [6]. Mając na uwadze zapobieżenie generowaniu nieuzasadnionych kosztów, CNBOP-PIB wykonuje ocenę WTO po otrzymaniu sprawozdań zawierających pozytywne wyniki dla wszystkich badań przewidzianych programem [7], [8]. Schematycznie proces dopuszczenia został przedstawiony na ryc. 5 .

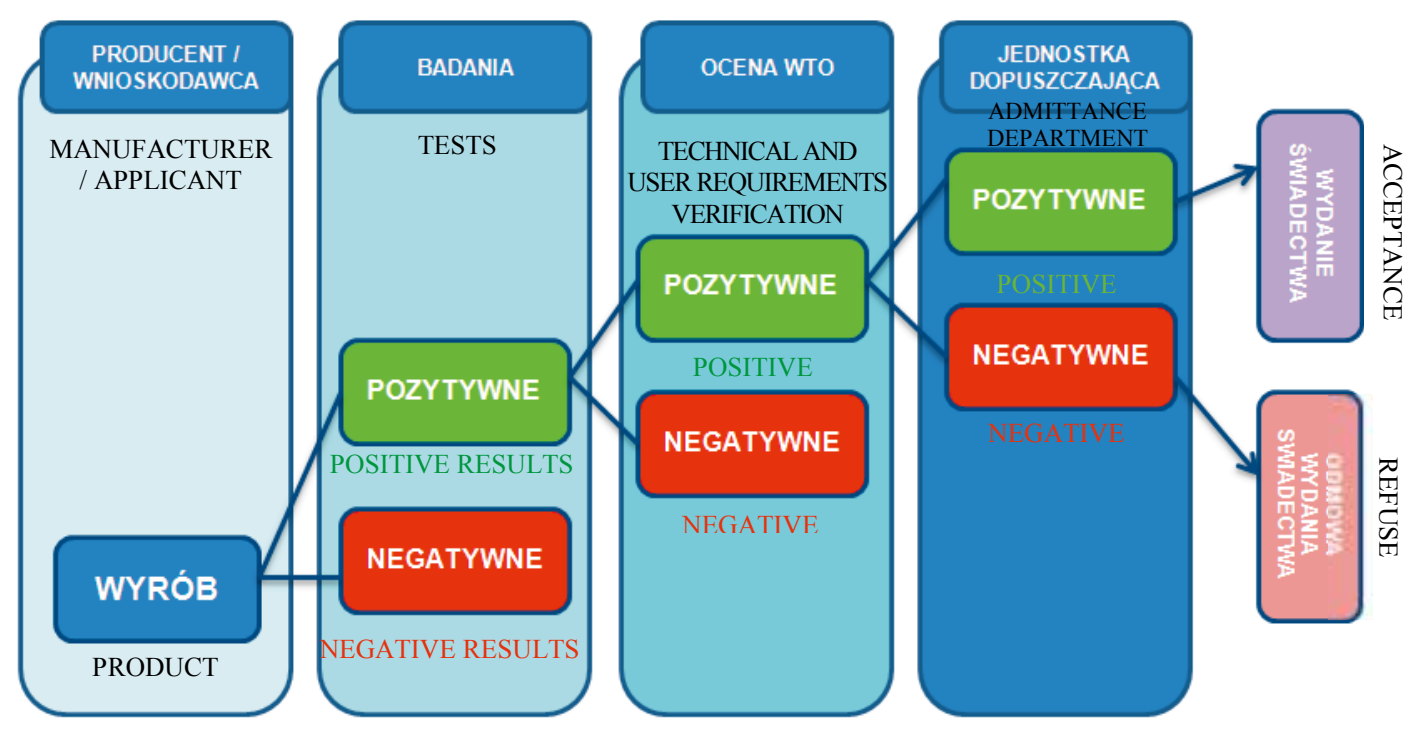

Ryc. 5. Schemat procesu dopuszczenia do użytkowania

Fig. 5. Admittance process scheme

Źródło: Opracowanie własne.

Source: Own elaboration. 
Zwieńczeniem procesu jest wydanie świadectwa dopuszczenia dla wyrobu. Dokument ten wydawany jest na okres nie dłuższy niż 5 lat. Główne założenia dopuszczenia do użytkowania przedstawione zostały na ryc. 6.

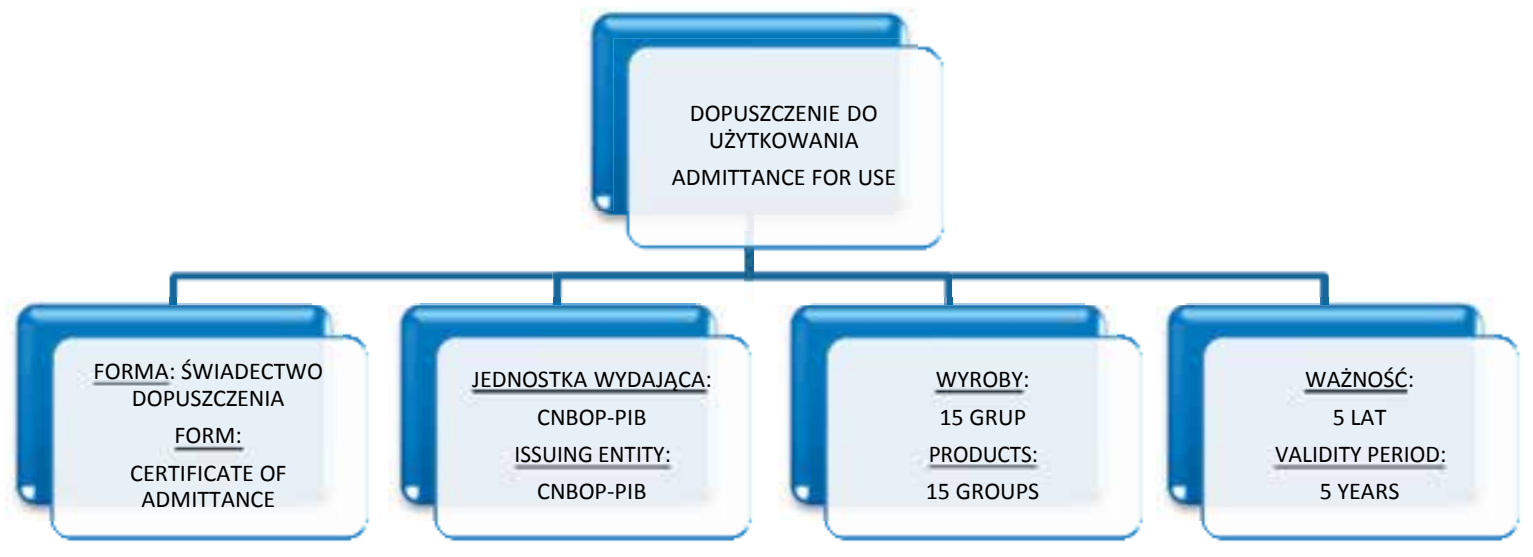

Ryc. 6. Główne założenia dopuszczenia do użytkowania

Fig. 6. Main assumptions of the admittance process

Źródło: Opracowanie własne Source: Own elaboration.

Należy zwrócić uwagę, że wydanie dopuszczenia to nie koniec roli CNBOP-PIB w procesie oceny zgodności wyrobu. Udzielone dopuszczenia podlegają kontroli. Kontrola realizowana jest corocznie i polega na weryfikacji wybranych cech oraz właściwości techniczno-użytkowych pojazdu pożarniczego w celu potwierdzenia, że w dalszym ciągu spełnia on określone wymagania i nie został zmodyfikowany bez wiedzy jednostki dopuszczającej (CNBOP-PIB) w sposób, który może mieć wpływ na jakość, właściwości oraz bezpieczeństwo użytkowania pojazdu. Dzięki przeprowadzaniu kontroli w okresie poprzedzającym wygaśnięcie świadectwa, ujawnionych zostaje wiele rodzajów niezgodności, które niewykryte mogłyby zagrażać życiu lub zdrowiu użytkowników.

\section{Kontrola udzielonego dopuszczenia}

Działalność CNBOP-PIB jako jednostki dopuszczającej nie ogranicza się tylko i wyłącznie do prowadzenia badań, procesu oraz kontroli udzielonego dopuszczenia. $\mathrm{W}$ uzasadnionych przypadkach, kiedy istnieje podejrzenie, że dany wyrób nie jest tożsamy z wyrobem dopuszczonym do użytkowania, CNBOP-PIB dokonuje porównania budzącego wątpliwości wyrobu $\mathrm{z}$ wzorcem, który był przedmiotem badań podczas prowadzonego procesu. W przypadku wyrobów takich jak samochody pożarnicze, których wysoka wartość oraz znaczne gabaryty powodują, iż nie ma możliwości magazynowania wzorców, wyrób porównywany jest $z$ dokumentacją techniczną, która została wykorzystana w procesie badań oraz w procesie dopuszczenia. Wynikiem porównań, o których mowa, jest protokół porównania zawierający wyniki szczegółowej i wnikliwej analizy zgodności wyrobu z wzorcem. Niestety w większości przypadków wątpliwości w stosunku do wyrobu zostają potwierdzone. Efektem negatywnego wyniku porównania jest podjęcie przez CNBOP-PIB stosownych działań mających na celu zidentyfikowanie przyczyn zaistniałych rozbieżności, które realizowane jest w formie kontroli doraźnej. Zakres badań kontroli doraźnej określany jest indywidualnie na podstawie informacji uzyskanych od użytkowników zgłaszających swoje zastrzeżenia co do dopuszczonego wyrobu. Konsekwencją kontroli doraźnej może być cofnięcie udzielonego dopuszczenia.

Uwagi do wyrobów w większości przypadków są zgłaszane przez użytkowników końcowych, np. komendy PSP. Zdarzają się jednak sytuacje, w których konieczność przeprowadzenia porównania wyrobu ze wzorcem jest związana z realizacją obowiązków przez takie instytucje jak policja czy CBA. CNBOP-PIB, będąc jednostką odpowiedzialną za prowadzone badania oraz procesy dopuszczeń wyrobów do użytkowania, podejmuje aktywną współpracę ze wspomnianymi organami oraz wieloma innymi instytucjami, np. UOKiK-iem, zawsze wtedy, gdy zajdzie taka potrzeba. Należy jednak zaznaczyć, iż CNBOP-PIB nie prowadzi działań wspierających lub działań opozycyjnych w stosunku do swoich klientów w odniesieniu do rozwiązywania konfliktów lub sporów sądowych (nie jest stroną w prowadzonych postępowaniach). Jednakże na wniosek uprawnionych organów, Instytut jest zobowiązany do udzielenia wszelkich niezbędnych wyjaśnień.

Należy pamiętać, iż świadectwa dopuszczenia nie mają charakteru otwartego. Wydawane są na jednoznacznie zidentyfikowany wyrób / odmiany wyrobu zakwalifikowane do grupy i/lub typu wyrobu. Przedmiotem dopuszczenia pojazdu jest ściśle określona próbka wyrobu, a na producencie / właścicielu dopuszczenia spoczywa odpowiedzialność za oferowanie pojazdu zgodnego z udzielonym dopuszczeniem. Wydane świadectwo dopuszczenia dotyczy tylko pojazdów pożarniczych wymienionych na tym świadectwie z uwzględnieniem zastosowanych wariantów (jeśli dotyczy). Wszelkie zmiany mogące mieć wpływ na właściwości użytkowe wyrobu (np. materiałowe, konstrukcyjne lub technologiczne) w okresie ważności dopuszczenia mogą 
być dokonywane wyłącznie za zgodą jednostki dopuszczającej (tj. CNBOP-PIB), która po analizie charakteru wprowadzonych zmian oraz wszelkiej dokumentacji temu towarzyszącej podejmuje decyzję o rozszerzeniu bądź ograniczeniu zakresu udzielonego dopuszczenia. Nie wszystkie rejestrowane i zgłaszane zmiany znajdują stosowne odzwierciedlenie w zapisach ujętych na świadectwach dopuszczenia. W niektórych przypadkach opisanie takiej zmiany nie jest możliwe (np. zmiana radiostacji, zmiana akumulatora). Świadectwo dopuszczenia zawiera podstawowe, wystandaryzowane dane techniczne identyfikujące wyrób. Szczegółowe informacje związane z opisem, parametrami pojazdu są umieszczone w sprawozdaniu z badań oraz homologacji podwozia stanowiących podstawę do wydania świadectwa dopuszczenia.

Potwierdzenie zgodności wyrobów w procesie dopuszczenia jest wypadkową oceny właściwości użytkowych (cech) reprezentatywnych próbek wyrobu poddanych uprzednio badaniom (najczęściej w warunkach laboratoryjnych) oraz oceny warunków techniczno-organizacyjnych produkcji w zakładzie produkującym przedmiotowy wyrób. Zasadniczym celem oceny warunków techniczno-organizacyjnych (WTO) jest potwierdzenie, że wyroby, które uzyskają dopuszczenie będą dostarczane użytkownikom o właściwościach i parametrach nie gorszych niż próbka wyrobu będąca przedmiotem badań w Laboratorium. Jako że jest ona systematycznym, niezależnym, udokumentowanym procesem uzyskiwania dowodów, stwierdzenia faktów bądź innych odpowiednich informacji oraz ich obiektywnej oceny i ma na celu określenie stopnia spełnienia wymagań, które zapewniają stabilną jakość produkcji wyrobów, ocena ta ma kluczowe znaczenie w procesie dopuszczania wyrobu do użytkowania. Wyciągnięcie wniosków ze stwierdzonych podczas oceny WTO niezgodności i spostrzeżeń niewątpliwie przyczynia się do podniesienia jakości ocenianych wyrobów. Należy podkreślić, iż prowadzenie ocen WTO zgodnie z opracowanymi przez CNBOP-PIB kryteriami zawartymi w dokumentacji systemowej gwarantuje sprawiedliwe podejście do wszystkich ocenianych organizacji. Kontrola dopuszczenia natomiast jest skutecznym oraz niezbędnym narzędziem zapewniania zgodności wyrobów z wymaganiami dokumentów odniesienia poprzez ciągłe nadzorowanie w okresie ważności świadectwa dopuszczenia.

\section{Podsumowanie}

Użyteczność systemu dopuszczeń dla jednostek ochrony przeciwpożarowej jest znacząca. Dostarcza on bowiem odbiorcom istotnych informacji na temat wyrobów, co ułatwia podjęcie decyzji o zakupie danego wyrobu. Ocena zgodności realizowana na potrzeby procesu dopuszczenia wyrobu do użytkowania w sposób naturalny reguluje jakość wyrobów na wolnym rynku, eliminując te, które klasyfikuje się na niższym poziomie jakościowym. Gwarancją rzetelności oceny zgodności wyrobu ze stawianymi mu wymaganiami prawnymi, technicznymi i normalizacyjnymi jest przeprowadzenie jej przez niezależną instytucję - tzw. stronę trzecią. CNBOP-PIB posiada akredytację Polskiego Centrum Akredytacji stanowiące potwierdzenie posiadania odpowiednich kompetencji do prowadzenia procesów dopuszczenia i gwarantujące, że wszyscy klienci traktowani są tak samo. Idea systemu dopuszczeń niesie za sobą pozytywne skutki w postaci m.in. kompatybilności wyposażenia, środków technicznych i środków łączności, czy chociażby uniwersalnego i jednolitego wykonania wzorów oraz parametrów technologicznych odzieży oraz ochron osobistych używanych przez strażaków-ratowników.

\section{Wnioski}

System dopuszczeń wyrobów z zakresu ochrony przeciwpożarowej jest bez wątpienia skutecznym narzędziem ministra właściwego do spraw wewnętrznych w procesie zapewnienia ochrony życia i zdrowia ratowników i ratowanych, a także bezpieczeństwa pożarowego w obiektach budowlanych na terenie Rzeczypospolitej Polskiej. Wyroby służące zapewnieniu bezpieczeństwa publicznego lub ochronie zdrowia i życia oraz mienia, objęte postanowieniami rozporządzenia MSWiA, posiadające świadectwo dopuszczenia do użytkowania cieszą się większym zaufaniem użytkowników końcowych. Tym samym oczywiste wydaje się stwierdzenie, iż system dopuszczeń obejmujący wszystkie przedstawione $\mathrm{w}$ artykule etapy ma kluczowe znaczenie w selekcji pojazdów pożarniczych trafiających na polski rynek, a co za tym idzie, jest swego rodzaju gwarancją, iż wyrób ten, przy zachowaniu jego tożsamości $\mathrm{z}$ wzorcem będącym przedmiotem procesu, jest $\mathrm{w}$ pełni funkcjonalny oraz bezpieczny.

\section{Literatura}

[1] Ustawa z dnia 24 sierpnia $1991 \mathrm{r}$ o ochronie przeciwpożarowej (Dz.U. $1991 \mathrm{Nr}$ 81, poz. 351 z późn. zm.)

[2] Rozporządzenie Ministra Spraw Wewnętrznych i Administracji z dnia 20 czerwca 2007 r. w sprawie wykazu wyrobów służących zapewnieniu bezpieczeństwa publicznego lub ochronie zdrowia i życia oraz mienia, a także zasad wydawania dopuszczenia tych wyrobów do użytkowania (Dz.U. $\mathrm{Nr} 143$, poz. 1002), wprowadzone rozporządzeniem zmieniającym z dnia 27 kwietnia 2010 r. (Dz.U. Nr 85, poz. 553).

[3] PN-EN 1846-1:2011 Samochody pożarnicze - Podziat i oznaczenie.

[4] PN-EN 1846-2+A1:2013-07 Samochody pożarnicze-Część 2: Wymagania ogólne - Bezpieczeństwo i parametry.
[5] Chmiel M., Markowski T., Kowalczyk A., Klasyfikacja, oznaczenie i podział pojazdów pożarniczych, BiTP Vol. 32 Issue 4, 2013, pp. 67-78

[6] Procedura Jednostki Certyfikującej CNBOP-PIB: P-8 Ocena warunków techniczno-organizacyjnych (WTO), edycja dziesiąta z 15.03.2013 r.

[7] Procedura Jednostki Certyfikującej CNBOP-PIB: P-20 Procesy wydawania, zmiany i cofania dopuszczenia, edycja czwarta z 31.07.2013 r.

[8] Informator o Świadectwach Dopuszczenia Jednostki Certyfikującej CNBOP-PIB, edycja czwarta, luty 2013 r. 
mgr inż. Ewa Sobór - absolwentka studiów I i II stopnia na Wydziale Inżynierii Bezpieczeństwa Cywilnego w Szkole Głównej Służby Pożarniczej w Warszawie (2001-2007). Od 2005 r. pracownik Jednostki Certyfikującej CNBOP-PIB. Aktualnie z-ca kierownika Jednostki Certyfikującej. Współautorka publikacji z zakresu bezpieczeństwa, ochrony przeciwpożarowej i zarządzania kryzysowego.

mgr inż. Marta Gołaszewska - absolwentka dziennych studiów I i II stopnia na Wydziale Inżynierii Bezpieczeństwa Pożarowego Szkoły Głównej Służby Pożarniczej. Od 2012 r. pracownik Jednostki Certyfikującej CNBOP-PIB.

mgr inż. Michał Chmiel - absolwent studiów I i II stopnia na Wydziale Inżynierii Bezpieczeństwa Pożarowego Szkoły Głównej Służby Pożarniczej. Od 2007 r. pracownik Jednostki Certyfikującej CNBOP-PIB. Aktualnie z-ca kierownika Jednostki Certyfikującej.

mgr inż. Michał Borusiński - absolwent studiów I i II stopnia na Wydziale Inżynierii Bezpieczeństwa Pożarowego Szkoły Głównej Służby Pożarniczej. Aktualnie doktorant III roku Akademii Obrony Narodowej na Wydziale Zarzadzania i Dowodzenia. Tematyka rozprawy doktorskiej w zakresie współpracy służb międzyresortowych MSW w kreowaniu bezpieczeństwa Państwa 